\title{
REGULATORY POLITICS AND SHORT SELLING
}

\author{
Erik R. Sirri*
}

\begin{abstract}
The SEC has plenary authority over the short selling of exchangeregistered securities. In the past it has altered the regulatory framework for short selling only occasionally, relying primarily on no-action letters to guide evolving practices and issues. Since early 2008, the SEC promulgated, either on a proposing, final, interim-final, or emergency basis, a raft of rules related to short selling, all of which generally restrict the ability of investors to sell stocks short. Much of this rulemaking reverses a course of policy set out by the SEC to carefully balance efficiency and market quality issues. This paper considers various reasons the SEC may have struck out on such a divergent course. In particular, it highlights the role of external influences on the SEC as it relates to short selling policy.
\end{abstract}

\section{INTRODUCTION}

Beginning in mid-2007, the financial sector came under a great deal of stress, particularly in the credit markets. The harbinger of what was to come was the April 2007 bankruptcy of New Century Financial, a California-based mortgage lender active in the origination of lower-quality mortgages. The bankruptcy of New Century Financial was soon followed by problems at two hedge funds run by Bear Stearns that necessitated the suspension of shareholder redemptions, explicit financial support from the funds' sponsor, and eventual liquidation of the funds. Credit markets began to freeze up in late 2007 with concerns over certain types of mortgage-related instruments backed by Alt-A and subprime mortgages. The first quarter of 2008 saw the demise of Bear Stearns and a further deepening of the credit crisis. As the year went on, there were severe financial difficulties for a number of financial

* Babson College, Wellesley, MA 02457, (508) 655-1068, sirri@babson.edu. A version of this paper was presented at the University of Pittsburgh School of Law Symposium on "The Past, Present, and Future of the SEC." I would like to thank participants at the Federal Reserve Bank of Atlanta conference on "Short Selling: Costs and Benefits for helpful comments." I would also like to thank the Division of Research at Harvard Business School for research support during my sabbatical. All errors and omissions are my own responsibility. 
intermediaries, both large and small, culminating in the failure of Lehman Brothers and the government rescue of AIG. ${ }^{1}$

This period of time was notable for the level of direct government involvement in financial markets and firms. Although there were numerous instances of government involvement, the most well known was the $\$ 700$ billion Troubled Asset Relief Program (TARP). As just one example, in September 2008 the government put in place three separate facilities to aid players in the short-term commercial market, including issuers, investors, and money market funds. The programs consisted of the Fed's Asset-Backed Commercial Paper Money Market Liquidity Facility (AMLF), the Fed's Money Market Investor Funding Facility (MMIFF), and the Treasurysupported Guaranty Program for Money Market Funds. ${ }^{2}$

At the same time, the Securities and Exchange Commission (SEC) was grappling with a different set of pressures and forces. Since the failure of Bear Stearns, various commentators had been suggesting that short sellers were responsible for the sharp decline, and in some cases, the demise, of various U.S. financial firms. ${ }^{3}$ Congressional leaders had repeatedly been calling for the SEC to re-evaluate policies and rules related to short selling. The matter became sufficiently salient that Senator John McCain, in a national televised speech as a Presidential candidate, called for modification of trading rules related to short selling and for the removal of the current SEC Chairman. ${ }^{4}$

The SEC's policy with respect to short selling has primarily been concerned with two different sets of rules. The first is known as the "uptick rule," and requires that short sales only be effected when the market in a stock was rising. The second set of rules requires that a short seller obtain or "locate" the stock to borrow before going into the market to sell it short. It also restricts the ability of brokers to execute short sales in shares of a particular issuer if enough other short sellers have "failed to deliver" shares

1. For a complete history of the credit crisis, see the timeline posted by the Federal Reserve Bank of New York Timelines of Policy Responses to the Global Financial Crisis, http://www.ny.frb.org/research/ global_economy/policyresponses.html (last visited Dec. 7, 2009).

2. See generally Davis Polk, Financial Crisis Manual: A Guide to the Laws, Regulations AND CONTRACTS OF THE FinANCIAL CRISIs (2009) (providing a description of federal actions during the credit crisis).

3. See, e.g., Gary Weiss, Wall Street Conspiracy Theories Dissected, Defined, Wash. Post, Nov. 22, 2009.

4. Senator John McCain, Address in Cedar Rapids, Iowa, (Sept. 17, 2008), in Jane Sasseen, McCain to Cox: You're Fired, Bus. WK., Sept. 18, 2008, available at http://www.businessweek.com/ election/2008/blog/archives/2008/09/mccain_to_cox_y.html. 
associated with earlier short sales. These rules are described in more detail in Sections 2 and 3 below.

Between July 2008 and April 2009, the SEC's activity on the rulemaking front with respect to short selling rose to an unprecedented level. In a period of ten months, the SEC took more than 15 regulatory actions on short selling, either as proposed, final, interim final, or emergency rules. Eleven of these rules came within a span of two months. More surprising still was the regulatory direction of much of this rulemaking. Over the preceding few years, the SEC had gradually been loosening restrictions on short selling in some dimensions, and tightening restrictions in others, though in a measured and gradual way. The new batch of 2008 and 2009 rules were largely orthogonal to, and in some cases in opposition to, recent rulemakings on short selling.

The rapid SEC rulemaking was unusual in other ways as well. For one, the SEC's general method of rulemaking is to use a public "notice and comment" process in which proposed rules are put out for months of public comments before being finalized. For the 2008-2009 rules, many were done using emergency and temporary rulemaking authority in which the rules came into force without a prior opportunity for public comment. Second, these rules all tightened the restrictions on short selling while offering very little justification for doing so, running contrary to the policy direction taken over the previous few years. In some cases, the SEC actually reversed itself over a one-month period with respect to the substance of the new rules. Third, the language of the rules was unusual, using terms like "confidence" as justification for the rule amendments, which is not at all typical of the agency's drafting.

The SEC's anomalous actions regarding short selling form the subject of this paper. In the next section, I describe the SEC's positions on short selling up until 2008, and the underlying logic of those positions. Section 3 describes the regulatory changes with respect to short selling that occurred from early 2008 through mid-2009. The fourth section examines various explanations for what might have caused the rapid rulemaking. The final section discusses several implications of the analysis and concludes.

\section{SEC Policy on Short Selling Before Mid-2008}

A short sale is a type of trade in which an investor sells a security that she does not own, the shares of the security being borrowed from a willing 
lender. ${ }^{5}$ The short sale is typically accomplished in three steps. First, the seller must locate a shareholder who will agree to lend his holdings of stock for a period of time, though the shares are generally not immediately borrowed. Next, the shares are sold on an exchange or otherwise, and the trade is marked "short" for trade reporting purposes. Finally, delivery occurs on the third day after the sale by the seller actually borrowing the shares from the lender and delivering them to the broker to fulfill her settlement obligation. The seller may maintain the short position going forward until she decides to close out, or "cover," the position by purchasing sufficient shares in the open market and returning them to the lender. Alternatively, the lender may demand the return of their borrowed shares by "calling" the shares in, forcing the short seller either to find another lender for the shares or to purchase new shares in the open market for return to the lender. ${ }^{6}$

Short sales occur for any number of reasons. One is the oft-cited reason that the investor thinks that the shares sold short will decline in value, allowing them to be repurchased in the marketplace at a lower price than that the price at which they were sold short. This price decline yields a trading profit for the short seller. However, there are many other reasons to sell stock short that are not motivated by expectations of future price declines. For example, a trader engaged in convertible bond arbitrage may own a convertible bond that contains an embedded call option on the issuer's stock. As part of a hedging strategy for the bond, the trader may wish to sell the issuer's stock short while simultaneously holding the long bond position, thereby capturing pricing discrepancies in the value of the embedded call. Such a trader would not necessarily have a view on the future direction of the market. Other reasons for shorting stock might include hedging long positions in swaps or restricted stock, or strategies related to statistical arbitrage.

Short selling often attracts the ire of various stakeholders in the financial system. Because many see it only as betting against the fortunes of the issuer whose stock is sold short, for some it has taken on a negative connotation. For example, in response to a proposal to make a relatively minor rule modification in July 2006 to narrow or eliminate certain exceptions to the delivery requirement for short sellers, the SEC received over 1000 comment letters, most of them from individual investors, many condemning the

5. Short selling can be performed for many types of financial claims, but for the purposes of this paper I consider short selling only with respect to listed equity securities.

6. There are other methods for the borrower of the shares to obtain shares for return to the lender. For example, the borrower may own a debt security that can be converted into common shares, or the borrower may have restricted shares that over time will become freely tradable in the marketplace. 
speculation associated with short selling. ${ }^{7}$ Moreover, legislators such as Congressman Barney Frank, Chairman of the House Financial Services Committee, have written the SEC Chairman with concerns about naked short selling during the 2008 market crisis. ${ }^{8}$

Controversy associated with speculation and short selling is nothing new. In eighteenth century England, in the aftermath of the South Sea Bubble, Parliament was concerned that speculation was causing harm to financial markets. The concern is typified in the following bit of doggerel of the time:

Whate'er the wretched basely dare

From Pride, Ambition, or Despair,

Fraud, Luxury, or Dissipation,

Assumes the Name of-SPECULATION ${ }^{9}$

This concern came to the fore when Parliament passed Sir John Barnard's Act in 1735, one of the first pieces of English securities legislation. Appropriately enough, the law partially concerned short selling. The Act "declared void all contracts for the sale of stock which the seller was not actually possessed of or entitled to at the time the contract was entered into." 10 Thus the law effectively prohibited short selling by forbidding the sale of borrowed shares. Popular concerns about short selling continue to this day. Thus it should not be surprising that an iconic magazine such as Rolling Stone would place on its cover, superimposed on a picture of the U2 lead singer Bono, the headline for a story about how short selling was responsible for the failure of Bear Stearns in March 2008. ${ }^{11}$

Regulatory responsibility for short selling falls exclusively to the SEC, whose policy on short selling can be bifurcated into two strands that, for the most part, operate independently. The first strand relates to price tests that must be met before a share can be sold short. The second strand concerns obligations and penalties associated with failures in the delivery of shares that are borrowed and sold short.

7. See Amendments to Regulation SHO, 71 Fed. Reg. 41710-22 (proposed July 21, 2006) (to be codified at 17 C.F.R. pt 242). See also Comments on Proposed Rule: Amendments to Regulation SHO, http://www.sec.gov/comments/s7-12-06/s71206.shtml (last visited Jan. 19, 2010).

8. See Letter from Rep. Barney Frank, Chairman, House Comm. on Fin. Servs., to Christopher Cox, Chairman, Sec. \& Exch. Comm'n (Apr. 4, 2008), available at http://www.house.gov/apps/list/press/ financialsves_dem/press0404083.shtml.

9. Stuart Banner, Anglo-American Securities Regulation 89 (Cambridge University Press 1998).

10. Id. at 105 .

11. Matt Taibbi, Wall Street's Naked Swindle, Rolling Stone, Oct. 15, 2009, at 50-59. 
Price tests

The Securities Exchange Act of 1934 (“1934 Act”) grants the SEC plenary authority over short sales. Section 10(a)(1) of the 1934 Act states that:

\begin{abstract}
It shall be unlawful for any person, directly or indirectly, by the use of any means or instrumentality of interstate commerce or of the mails, or of any facility of any national securities exchange - to effect a short sale, or to use or employ any stop-loss order in connection with the purchase or sale, of any security registered on a national securities exchange, in contravention of such rules and regulations as the Commission may prescribe as necessary or appropriate in the public interest or for the protection of investors.
\end{abstract}

This Section was first made operational by the SEC in early 1938, through the promulgation of rule 10a-1 of the 1934 Act, more colloquially known as the "uptick rule." 12 According to Joel Seligman's account of the history of the SEC, passage of the rule 10a-1 was part of a strategic contest between the SEC and the NYSE over reform of the Exchange and was unusual in that it was the first time the SEC itself passed a rule governing the Exchange instead of having the Exchange draft its own rule. ${ }^{13}$ Rule 10a-1 reads, in relevant part,

\footnotetext{
It shall be unlawful for any person . . . [t]o effect a short sale . . of any security registered on a national securities exchange, ... :

A. Below the price at which the last sale thereof, regular way, was reported pursuant to an effective transaction reporting plan; or

B. At such price unless such price is above the next proceeding different price at which a sale of such security, regular way, was reported pursuant to an effective transaction reporting plan. ${ }^{14}$
}

In effect, the rule meant that a short sale could only occur if the sale was at higher price that the previous trade, or if at the same price as the previous trade, then only if that price was higher than the previous different price. It was intended to have the effect of prohibiting short sales in falling markets, and was in part motivated by a Commission study of concentrated short selling during periods of stress in 1937.

12. See Douglas M. Branson, Nibbling at the Edges-Regulation of Short Selling: Policing Fails to Deliver and Restoration of an "Uptick" Rule, 65 Bus. Law. 67, 67-94 (2009) (providing a comprehensive analysis of recent SEC policy with regard to short sales).

13. Joel Seligman, The Transformation of Wall Street 165 (Aspen 3d ed. 2003).

14. 17 C.F.R. $\S 240.10 \mathrm{a}-1$ (2009). 
It is important to note that when the rule was drafted in 1938, exchange trading was much different than it is today. First, stocks traded in increments of $1 / 8$ th of a dollar, or 12.5 cents. This is a large increment compared to the penny increment of today. Also, at that time there was no electronic trading of stocks so that more trade took place on exchange and at a slower pace than today. For example, while the NYSE traded on average of 2.2 billion shares per day for the first eleven months of 2009, in 1940 the Exchange traded on average 1.13 million shares per day, or about $1 / 2000$ th of the volume it trades today. ${ }^{15}$

In recent times, administration of rule 10a-1 was primarily through the no-action letter process, yet the SEC recognized that the rule was of limited effectiveness. For one, the rule only applied to exchange-registered securities, and up until January 2006, NASDAQ was not yet a registered securities exchange. Thus the NASD and NASDAQ were subject instead to a bid test that applied only to NASDAQ Global Market Securities. However if these same securities traded on exchanges other than NASDAQ, they were not subject to any price test. ${ }^{16}$ Furthermore, over the years a number of exceptions and exemptions had been granted through no-action letters that rendered rule 10a-1 less effective. ${ }^{17}$ Exemptions to the uptick rule had been granted for Exchange Traded Funds (ETFs), for electronic crossing markets, and for specialists and market makers facilitating customer market and marketable limit orders at the NBBO. ${ }^{18}$ In addition, in 2007, the exchanges were all trading in penny increments instead of the 12.5 cent increments of 1938. As a result, the permissible last sale price difference calculated under the rule was only one cent- a stock could be sold short under rule 10a-1 if the trade was just one cent above the previous price, a very small increment. Because stock prices vibrate randomly, and spreads were often larger than one cent, this difference became almost meaningless. These conclusions were empirically supported by the SEC's own study of a pilot sample of stocks that were exempted from rule 10a-1 for a period of time. ${ }^{19}$ The SEC staff concluded that the rule had little effectiveness and should be rescinded.

15. NYSE, Technologies Market Data, http://www.nyxdata.com/nysedata/asp/factbook/viewer interactive. asp?hidCategory $=4$ (last visited Jan. 20, 2010).

16. 72 Fed. Reg. § 36348-59 n.11.

17. See Rule 10a-1(e), 17 C.F.R. pt. 240 (2009) (listing exceptions to the uptick rule).

18. See 71 Fed. Reg. $§ 75071-75072$ for a more complete discussion of the exemptions.

19. See SEC Office of Econ. Analysis, Economic Analysis of the Short Sale Price Restrictions Under the Regulation SHO Pilot, Feb. 6, 2007, http://www.sec.gov/news/studies/2007/regshopilot 020607.pdf (last visited Jan. 19, 2010). 
Accordingly, on July 28, 2007, the SEC formally rescinded rule 10a-1. In addition to removing the tick test, the SEC forbid any SRO from creating its own price test with respect to short sales. ${ }^{20}$ Interestingly, the December 2006 release proposing to remove rule 10a-1 received only 27 comment letters, and the ultimate rescinding of the rule in July 2007 received scant attention in the financial press.

\section{Delivery of shorted securities and Regulation SHO}

The second prong of the SEC's policy concerning short selling relates to the delivery of shorted shares. The SEC defines "naked short selling" as "selling short without borrowing the security to make delivery." ${ }^{11}$ The Commission was concerned about the harmful effects on the markets of failing to deliver securities. Failing to deliver a share converts ownership of a security into a forward contract, causing the buyer (or a clearing agency) to be exposed to the credit risk of the seller. It can also create problems with respect to the voting of shares as a buyer might not be in possession of the security at the required time and thus would lose the ability to vote. Over the years, the SEC had also become concerned that naked short selling was at times associated with various abusive and manipulative practices.

In response, the SEC adopted new Regulation SHO in August 2004. ${ }^{22}$ Among other things, Regulation SHO replaced disparate SRO rules with the requirement that a broker-dealer must either borrow, or arrange to borrow, or have reasonable grounds to believe the security can be borrowed before he can accept a short sale order in that security. In addition, it established the creation of a "threshold list" of securities for which the aggregate amount of fails to deliver at a registered clearing agency (here, only DTC) is greater than both 10,000 shares and one-half of one percent of the shares outstanding. If a security is on such a threshold list for a specified period of time, a broker-dealer who himself has failed to deliver shares must "close-out" this fail and, while the fail is open, cannot effect further short sales without pre-borrowing the security. The rule originally contained a number of exceptions from these requirements, including a provision for pre-existing fail positions (the grandfather exception) and an exception for options market makers.

\footnotetext{
20. Regulation SHO, 17 C.F.R. $\S 242.201$ (a)-(b) (2007). 242).

21. Short Sales, 68 Fed. Reg. 62,972, 62,975 (Nov. 6, 2003) (to be codified at 17 C.F.R. pts. 240,

22. See Short Sales, 69 Fed. Reg. 48008 (Aug. 6, 2004) (to be codified at 17 C.F.R. pt. 240-242).
} 
Regulation SHO was an attempt to reduce the number of fails to deliver in the settlement system. Along the way, the threshold list for the first time let the public see which names had substantial amounts of open fails to deliver. The SEC gradually moved to reduce the number of securities with substantial fails by tightening and/or eliminating some of the rules' exceptions. For instance, on August 7, 2007, the SEC eliminated the grandfather provision and proposed to eliminate the options market maker exception.

\section{SEC Short SELling Rules IN 2008-2009}

In this section I will describe the period of intensive SEC rulemaking with respect to short selling from early 2008 through mid-2009. I will not attempt to cover each rule filing related to short sales as such a discussion would be beyond the scope of this paper. But I will provide a discussion of the most important regulatory efforts over this period, which can be divided into six groupings. A chronology of SEC rule actions concerning short selling is shown in Exhibit 1.

\section{A. "Naked" Short Sale Anti-Fraud Rule}

Regulation SHO prohibits a broker dealer from (i) accepting a short sale order from another person, or (ii) effecting a short sale for their own account, unless the broker dealer has borrowed, made an arrangement to borrow, or has reasonable grounds to believe the security can be borrowed so that it can be delivered at the settlement date. ${ }^{23}$ This is known as obtaining a "locate" in the security. The rule thus operates as a requirement on the broker-dealer. Regulation SHO places no obligations on the ultimate customer of the broker-dealer with regard to their short sales.

The Commission became aware that at times a broker-dealer might be deceived by a customer who claimed to have a locate for a security when in fact they had not identified a willing lender. Because a broker-dealer is allowed to rely on the representations of a customer with respect to a locate, the broker-dealer might fail to deliver through no fault of its own. Accordingly, on March 17, 2008, the Commission proposed an anti-fraud rule associated with "naked" short selling that targeted misrepresentation by customers. ${ }^{24}$ Rule $10 \mathrm{~b}-21$ states that:

23. Regulation SHO, 17 C.F.R. § 242.203 (2007).

24. See Naked Short Selling Anti-Fraud Rule, 73 Fed. Reg. 15,376 (Mar. 21, 2008) (to be codified 
It shall constitute a "manipulative or deceptive device or contrivance" as used in section 10(b) of this Act for any person to submit an order to sell a security if such person deceives a broker or dealer, a participant of a registered clearing agency, or a purchaser about its intention or ability to deliver the security on the date delivery is due, and such person fails to deliver the security on or before the date delivery is due..$^{25}$

Though some have observed that such a rule may be redundant given the reach of rule 10b-5, the Commission felt that it was important to emphasize the specific liability of persons who deceive broker-dealers about their ability to fulfill their delivery obligations for short sales. The rule was adopted by the Commission on October 14, 2008, after they received more than 700 comment letters on the proposal. ${ }^{26}$ However, it was implemented on a temporary basis by a $12(\mathrm{k})(2)$ emergency order on September 17, 2008. ${ }^{27}$

\section{B. The First 12(k)(2) Emergency Order: Mandatory Pre-Borrowing to Short Certain Financial Firms}

On July 15th, 2009, the SEC issued the first of a series of emergency orders pursuant to its authority under Section 12(k)(2) of the 1934 Act. Section 12(k)(2) gives the Commission the authority to act in an emergency and make rules within its normal purview, but without following the traditional notice and comment process. ${ }^{28}$ Such Orders can be effective for up to thirty calendar days, including extensions. The July 15 Order required that for a group of nineteen indentified financial firms,

at 17 C.F.R. pt. 240).

25. 17 C.F.R. $\S 240.10 b-21$ (2008).

26. See Naked Short Selling Anti-Fraud Rule, 73 Fed. Reg. 61,666 (Oct. 17, 2008) (to be codified at 17 C.F.R. pt. 240).

27. Emergency Order Pursuant to Section 12(k)(2), Exchange Act Release No. 58572, 94 SEC Docket 293 (Sept. 17, 2008).

28. Section $12(\mathrm{k})(2)$ states:

The Commission, in an emergency, may by order summarily take such action to alter, supplement, suspend, or impose requirements or restrictions with respect to any matter or action subject to regulation by the Commission or a self-regulatory organization under this title, as the Commission determines is necessary in the public interest and for the protection of investors (i) to maintain or restore fair and orderly securities markets (other than markets in exempted securities); or (ii) to ensure prompt, accurate, and safe clearance and settlement of transactions in securities (other than exempted securities).

15 U.S.C. § 78(1) (2004). 
$[\mathrm{N}] \mathrm{o}$ person may effect a short sale in these securities using the means or instrumentalities of interstate commerce unless such person or its agent has borrowed or arranged to borrow the security or otherwise has the security available to borrow in its inventory prior to effecting such short sale and delivers the security on settlement date. ${ }^{29}$

This essentially required short sellers to pre-borrow the security before they sold it short. The nineteen firms covered by the Order consisted of Fannie Mae, Freddie Mac, and the seventeen primary dealers in Treasury securities. ${ }^{30}$

A pre-borrow requirement is a significant change from standard industry practice. To comply with the Order, a seller must actually borrow the shares or establish an exclusive arrangement to borrow the shares, known as a "hard locate," before the sale is effected. This differs from the usual situation where a short seller can locate the shares before the sale but not actually take possession of them until just before delivery. Pre-borrowing also means that the a set of shares can only be pledged to one short seller who ultimately may or may not actually borrow them, as opposed to being pledged to multiple potential short sellers.

This Order was modified three days later by providing a number of amendments to the Order's scope. ${ }^{31}$ For example, the Order excepted registered market makers, block positioners, and other market makers in certain circumstances, as well short sales effected pursuant to Rule 144 of the Securities Act of 1933.

\section{The Second 12(k)(2) Emergency Order: Tightening Regulation SHO Delivery Requirements}

On September 17, 2009, the SEC issued a 12(k)(2) Order imposing enhanced delivery requirements on brokers with respect to the sales of all equity securities. ${ }^{32}$ Similar to the previous emergency Order, the Commission

29. Emergency Order Pursuant to Section 12(k)(2), Exchange Act Release No. 58166, 93 SEC Docket 2122 (July 15, 2008).

30. The seventeen dealers were recently given access to the newly-created Primary Dealer Credit Facility (PDCF), an overnight facility that makes collateralized loans to insure the liquidity of the dealers. See Bd. of Governors of the Federal Reserve, Federal Reserve Announces Establishment of Primary Dealer Credit Facility, Mar. 16, 2008, http://www.newyorkfed.org/newsevents/news/markets/2008/rp080316.html (last visited Jan. 20, 2010).

31. Amendment to Emergency Order Pursuant to Section 12(k)(2), Exchange Act Release No. 58190, 93 SEC Docket 2255 (July 18, 2008).

32. Emergency Order Pursuant to Section 12(k)(2), Exchange Act Release No. 58572 (Sept. 17, 2008). 
justified the Order by their concern "about the possible unnecessary or artificial price movements based on unfounded rumors regarding the stability of financial institutions and other issuers exacerbated by 'naked' short selling." ${ }^{, 33}$ Rule $204 \mathrm{~T}$ penalizes a member of any clearing agency (the broker) for having a fail to deliver in any stock, whether from a long or a short sale. The fail must be closed out by the morning of the day after settlement. If the clearing member fails to do this, they must pre-borrow or enter into a bona-fide arrangement to borrow the security before effecting a short sale in that security, thereby imposing a hard locate requirement.

The Order also did two other things. First, it caused rule 10b-21, the naked short selling anti-fraud rule, to become immediately effective. The rule had been proposed in March 2008 but had not yet adopted. Second, it immediately closed the options market maker exception under Regulation SHO. This Order was later amended on October 1, 2009, to incorporate technical guidance from Commission Staff into the Order itself, and to extend the Order's effectiveness to 30 calendar days. ${ }^{34}$

\section{The Third 12(k)(2) Emergency Order: Banning Short Sales in All Financial Firms}

On September 18, the SEC issued the most draconian of its various emergency Orders, using its Section 12(k)(2) authority to ban all short sales in a large group of financial firms, including all banks, insurance companies, and securities firms. ${ }^{35}$ The list ultimately contained approximately a thousand financial firms. The Commission's justification for the Order was their concern

that short selling in the securities of a wider range of financial institutions may be causing sudden and excessive fluctuations of the prices of such securities in such a manner so as to threaten fair and orderly markets.

Given the importance of confidence in our financial markets as a whole, we have become concerned about recent sudden declines in the prices of a wide range of securities. Such price declines can give rise to questions about the underlying financial condition of an issuer, which in turn can create a crisis of confidence, without a fundamental underlying basis. ${ }^{36}$

33. Id.

34. Order Extending Emergency Order Pursuant to Section 12(k)(2), Exchange Act Release No. 58711 (Oct. 3, 2008).

35. Emergency Order Pursuant to Section 12(k)(2), Exchange Act Release No. 58592, 73 Fed. Reg. 55169-02 (Sept. 18, 2008).

36. Id. at 1 . 
The Order was also remarkable in its implementation, in that unlike some of the earlier Orders, it went into immediate effect. Market participants had only hours to adjust to the effect of the ban. ${ }^{37}$

This Order was subsequently amended two times. The first was three days later on September 21, when the SEC effectively transferred administration of the list of firms covered by the short sale ban to the SROs. ${ }^{38}$ That amendment also provided an exception from the short sale ban for market makers in derivatives on the Covered Securities, and for the ETFs and exchange-traded notes for which the Covered Security was a component. ${ }^{39}$ The second amendment was issued on October 2, and provided that the Order would expire three business days from the President's signing of the Emergency Economic Stabilization Act, or at the thirty day statutory limit for the Order, whichever came first. ${ }^{40}$

E. The Fourth 12(k)(2) Emergency Order: Public Reporting by Institutional Managers of Their Daily Short Positions and Trading

On September 18, the Commission issued an Order requiring institutional money managers with over $\$ 100$ million of assets under management to file a new Form SH on a weekly basis to detail short selling activity in the previous week. ${ }^{41}$ With respect to each covered security, the Form required the manager to report, on each day of the preceding week, "the number and value of securities sold short during the day as well as the opening short position, closing short position, largest intraday short position, and the time of the largest intraday short position, for that security on each calendar day of the prior week in which the institutional investment manager engaged in trading activity with respect to short sales." ${ }^{\prime 2}$ The Order required that the Form be filed electronically and be publicly available on EDGAR.

37. Id. The Order contained a provision that allowed any issuer covered by the ban to opt out of it if they chose to do so. Very few firms took advantage of this opportunity.

38. Emergency Order Pursuant to Section 12(K)(2), Exchange Act Release No. 58611, 94 SEC Docket 501 (Sept. 21, 2008).

39. Id.

40. Order Extending Emergency Order Pursuant to Section 12(K)(2), Exchange Act Release No. 58723, 94 SEC Docket 818 (Oct. 2, 2008).

41. Emergency Order Pursuant to Section 12(K)(2), Exchange Act Release No. 58591, 94 SEC Docket 312 (Sept. 18, 2008).

42. Id. at 4 . 
In justifying the Order, the Commission used language that was similar to the previous orders, citing concerns that stock prices were being affected by unfounded rumors and that short selling was harming confidence in the market. With regard to the public filing of Form SH, the Order stated it "will ensure transparency in short selling." ${ }^{43}$ This Order was modified three days later, on September 21, by a subsequent Order that permitted the Forms SH to be filed on a non public basis "in order to maintain fair and orderly securities markets and prevent substantial disruption in the securities markets." ${ }^{\prime 4}$ This seemed to negate the original purpose of the Order in ensuring short selling transparency.

\section{F. The Return of the Price Test}

The final installment in the SEC's burst of activity with respect to short selling occurred on April 10, 2009, when the Commission proposed a smorgasbord of rules to replace the 10a-1 uptick rule that was rescinded in July $2007 .{ }^{45}$ The release noted that the extreme market conditions and deterioration in investor confidence have caused many commenters to ask the SEC to reconsider its termination of the old uptick rule, and made it appropriate for the Commission to seek comment on a restriction for short selling. The release cited as a benefit of the proposed restriction that the rules "might help to prevent short selling, including potentially abusive or manipulative short selling, from driving the market down and from being used as a tool to accelerate a declining market." ${ }^{, 46}$ This justification is notable in the wake of what many regarded as an asset bubble, as well as the generally poor economic condition of a number of large financial firms.

The 273-page release amending Regulation SHO proposed four alternative price-driven tests. Two of the tests are variations on the old uptick rule and would apply permanently on a market-wide basis. The first of these is a price test based on the national best bid price, while the second is based on the last sale price (similar to the old rule 10a-1). The other two sets of price tests are both variants of a "circuit breaker" that apply only in times of stress in a particular security. In one of these tests, a severe price decline would trigger a temporary prohibition by any person from selling short that security.

43. $I d$.

44. Emergency Order Pursuant to Section 12(K)(2), Exchange Act Release No. 58591A, 94 SEC Docket 445, (Sept. 21, 2008).

45. 74 Fed. Reg. 42033-42037 (Aug. 20, 2009).

46. Id. at 18091. 
In the other type of "circuit breaker," the severe price decline would trigger some form of price test rule, whether based on the bid price or the last sale price.

As of the writing of this paper, the proposed rule has not been acted upon by the Commission, though on August 17, 2009 the Commission did reopen the comment period and supplement its request for comment on certain aspects of the proposals. ${ }^{47}$

\section{Analysis and Potential Causes of the Policy Shift in SHORT SELLING}

The SEC's regulatory effort with regard to short selling from 2008 to mid-2009 is remarkable. For one, the spate of rulemaking in this period was both rapid and broad, covering at least six different approaches to short sale regulation, as described in Section 3 above. But it was also remarkable in its substance. The orders and rules promulgated by the SEC over this period uniformly tightened restrictions on short selling, both on the "price test" and the "fail to deliver" branches of regulatory policy. These new policy directions stand in contrast to the previous direction the Commission had taken in this area. In July 2007, the Commission had rescinded the uptick rule, and the SEC had taken a measured approach to regulation of fails to deliver. It was only gradually tightening provisions associated with the grandfathering of old fail positions and the options market maker exception, and in each instance was empirically measuring progress and repeatedly seeking public comment. It is therefore reasonable to ask what caused the sudden and substantive change in the SEC approach to short selling regulation. There are a number of potential explanations for this policy shift, and I will examine each of these in turn.

One possibility is that the SEC had new evidence that its existing approach to regulating short sales was ineffective, so that the new rules and Orders reflected the Commission's attempt to shore up its rule set. However, there is nothing in the record or in the language of the SEC's rules and orders to suggest this is the case. Recall that the September 2008 12(k)(2) emergency orders began shortly after the failure of Lehman Brothers. Many of these orders focused on curbing naked short selling. But a review of the threshold lists of stocks shows that Lehman Brothers was not on the threshold list in the weeks leading up to its failure. That is, there may have been an active market in short selling Lehman's stock, but those short sales did not result in

47. 74 Fed. Reg. 43033-42037 (Aug. 20, 2009). 
persistent fails to deliver. Given its large public float, this is not a surprising for Lehman. More to the point, very few major financial names appeared on the threshold lists at all. Exhibit 2 shows the complete threshold list for NYSE-listed stock on September 12, 2008, shortly before Lehman failed. Not only is Lehman not on this list, neither is Citigroup, AIG, Morgan Stanley, Goldman Sachs, Wachovia, or any number of other stocks that were allegedly threatened by "naked" short selling. Though Freddie Mac is on the list, by this time it was under the conservatorship of the federal government.

The SEC cites the need to protect financial firms in these Orders. For example, in the September 18, 2008 Order banning short sales in all financial firms, the SEC states that their previous pre-borrow Order arose out of concerns

\begin{abstract}
about the possible unnecessary or artificial price movements based on unfounded rumors regarding the stability of financial institutions and other issuers exacerbated by naked short selling. Our concerns, however, are no longer limited to just the financial institutions that were the subject of the July Emergency Order. Recent market conditions have made us concerned that short selling in the securities of a wider range of financial institutions may be causing sudden and excessive fluctuations of the prices of such securities in such a manner so as to threaten fair and orderly markets. ${ }^{48}$
\end{abstract}

Yet as a group, these financial firms do not appear to be the subject of "naked" short selling, at least as evidenced by fails to deliver. Neither is academic evidence supportive of the notion that naked short selling contributes to prices declines. A recent paper by Boutlon and Braga-Alves finds no connection between the level naked short selling activity and future stock declines. Instead they find that naked short sellers are contrarians, selling short after price increases. The authors state that their results "are not consistent with the recent portrayal of naked short sellers as abusive and manipulative but instead suggest that naked short sellers promote efficient markets by providing liquidity, risk-bearing, and selling stocks they view as overpriced." ${ }^{49}$ Thus, while the shares of firms covered by Commission Orders were subject to selling pressure generally, the Commission's release offer no justification for the view that abusive short selling was causing any price distortions.

48. See Exchange Act Release No. 58592, 73 Fed. Reg. 55169-02 (Sept. 24, 2008).

49. Thomas J. Boulton \& Marcus V. Braga-Alves, Naked Short Selling and Market Returns, Apr. 6, 2009, at 18, available at www.frbatlanta.org/news/CONFEREN/09short_sell/Boulton.pdf. 
An examination of the language the SEC uses in their orders is revealing in this regard. In the July 15, 2008 Order requiring pre-borrowing before shorting the stock of nineteen firms, the Commission argues that false rumors can cause a lack of confidence, which can lead to panic selling that is exacerbated by naked short selling. The September 18 order banning all short sales makes a similar argument, but goes on to state that the ensuing price declines can lead to a loss of confidence. The word "confidence" appears in a significant number of the short sale orders and rules in this period, suggesting that the Commission was concerned with boosting confidence rather than traditional market quality issues.

With regard to the "uptick rule," there is similarly no evidence to date cited by the SEC to motivate its April 2009 proposal to bring back a short sale price test. In that release, the Commission cites the SEC staff's work to show that there was little justification for maintaining the price test in July 2007. It also pointed to the work of outside researchers and affirmed that they generally do not support short selling price tests. The release appears to argue that the Commission is considering reinstating price tests because certain commentators have been asking for such tests. Here too, the Commission points to investor confidence as a reason for the rule proposal. ${ }^{50}$ In this regard, the SEC was not alone. Duncan Niederauer, the head of NYSE Euronext, stated that while "there was no economic benefit" from having the uptick rule, "it would go a long way to adding confidence." ${ }^{51}$ Thus, in both the case of fails to deliver and price tests, the Commission does not provide explanations for its actions that suggest that the failure of existing rules led to the sudden rulemaking.

A second reason the SEC may have suddenly altered its short selling policy approach could stem from an enforcement-related event. For example, in the wake of the Madoff scandal at the end of 2008, the SEC proceeded to tighten certain custody rules for investment advisers. With regard to short selling, there has not been a group of enforcement actions around short selling that would seem to motivate such a shift. In April 2008, the SEC did charge a trader with fraud and market manipulation for intentionally disseminating false rumors around a merger transaction, but there has been little in this area since that action. In addition, I could find no public use of the daily institutional short selling data collected by the Commission during the

50. See Amendments to Regulation SHO, Exchange Act Release No. 34-59748, 74 Fed. Reg. 18042, at 18043 (proposed Apr. 10, 2009).

51. Gerry Shih, S.E.C. May Reinstate Rules for Short-Selling Stocks, N.Y. Times, July 3, 2009, at B1 
effective period of the September 18 12(k)(2) Order, either in enforcement or rulemaking proceedings. ${ }^{52}$ Nor has there been any technological change in the short selling process that would precipitate such a spate of regulatory actions.

An alternate possibility to explain the SEC's short sale actions from 2008 through the middle of 2009 relates to the political process as it affects the SEC. The SEC is an agency that is at once independent and beholden. It is an independent executive agency that functions outside the administration and, unlike a cabinet agency, has the ability to work without regard to the wishes of the President. On the other hand, the SEC is crafted as a political agency that must show responsiveness to Congress. The Commissioners are Presidential appointees, chosen so that no more than three are from the same party as the President, and are confirmed by Congress. In addition, the SEC is not self-funded so it must come to Congress annually to justify its programs and to seek funding for the coming year.

Though the influence that Congress and the administration exert on the SEC is traditionally modest, there is evidence that in the case of short selling policy during the credit crisis this external pressure rose to significantly higher levels. Congressman Barney Frank, the powerful head of the House Financial Services Committee, one of the SEC's two oversight committees, wrote to Chairman Christopher Cox on April 4, 2008, asking the SEC to widen one of its reviews to include trading in the stock of all investment banks, and stating the depending on the results, "this may lead to a broader inquiry into short selling by the SEC and Congress" ${ }^{" 53}$ Chairman Frank stated that he met also with Chairman Mary Schapiro to discuss short selling in general and the reinstatement of some form of the uptick rule in particular. ${ }^{54}$ The press has reported numerous accounts of Congressional pressure on the SEC for action on short selling. ${ }^{55}$

52. Emergency Order Pursuant to Section 12(k)(2), Exchange Act Release No. 34-58591, 73 Fed. Reg. 55, 175 (Sept. 18, 2008).

53. Letter from Rep. Barney Frank, Chairman, House Comm. on Fin. Servs., to Christopher Cox, Chairman, Sec. \& Exch. Comm'n (Apr. 4, 2008), available at http://www.house.gov/apps/list/press/ financialsvcs_dem/press0404083.shtml.

54. See Frank Ahrens; Report: Rep. Frank Says Uptick Rule Should Be Restored "Within a Month," WASH. Post, Mar. 10, 2009, available at http://voices.washingtonpost.com/economy-watch/2009/03/ report_rep_frank_sayz_uptick_r.html; Ronald D. Orol, Frank: Up-tick Rule to be Introduced in a Month, MARKETwATCh, Mar. 10, 2009, http://www.marketwatch.com/story/frank-up-tick-rule-introduceda?dist $=$ msr_13.

55. See Liz Moyer, Get Shorty, Forbes.COM, Apr. 7, 2008, http://www.forbes.com/2008/04/07/ trading-regulation-investing-biz-wall-cx_lm_0407lehman.html; Shih, supra note 51; Peter H. Stone, Regulators Want Short Leash for Short Selling, NAT'L J., Dec. 4, 2009; Ian Swanson, Pressured by Congress, SEC Looks into Shorting, THeHiLL.COM, Apr. 7, 2009, http://thehill.com/business-a-lobbying/ 
One of the most vocal Congressional critics of short selling was Senator Edward Kaufman, who wrote to Chairman Schapiro requesting action on various short selling fronts. ${ }^{56}$ His letter asks that the SEC reinstate the uptick rule and establish a permanent mandatory market-wide pre-borrow requirement for short sales. His concerns are all the more poignant because he is the sponsor of a Senate bill, S.605, to reinvent short sale regulation. ${ }^{57}$ Among other things, the bill requires the SEC to re-instate the uptick rule, allows SROs to draft their own price tests, requires short sellers to yield priority and preference in their transactions to long sellers, and significantly tightens share delivery requirements for short sellers. There are two other House bills with different but related schemes to direct the SEC in its regulation of short selling. One is H.R. 302, sponsored by Representative Gary Ackerman, and the other is H.R. 1406, sponsored by Representative Mark Kirk. Both of these two bills seek to reinstate the uptick rule. ${ }^{58}$ Collectively, the attention by Congress typified in their letters and comments, and the clear threats of Congressional legislative action have put pressure on the SEC to tighten regulatory restrictions on short selling.

One should also note that by early 2009, the SEC was significantly weakened as a financial regulator in Washington. The SEC had oversight of the major investment banks, most of which suffered various forms of financial difficulty. The Fed, Treasury, and others were critical of the manner in which the firms were supervised by the SEC, though the SEC's statutory responsibility was only for the broker-dealer subsidiaries. Worse by far was the crisis that erupted over Bernie Madoff's $\$ 50$ billion Ponzi scheme fraud, responsibility for which was clearly with the SEC. Against such a backdrop, SEC leadership may have been unwilling to risk losing whatever remaining support they had on Capitol Hill. With large-scale regulatory reform being negotiated, the Commission may not have wanted to risk losing a large portion of the agency's authority over as transitory a matter as short selling. Pleasing Congressional critics, especially those who sit on one's oversight committees, may have been an essential part of the SEC policy tradeoff.

4009-pressured-by-congress-sec-looks-into-shorting.

56. Letter from Senator Edward Kaufman to Mary Schapiro, Chair, Sec \& Exch. Comm'n (Mar. 3, 2009), available at $\mathrm{http}: / / \mathrm{kaufman}$. senate.gov/press/press_releases/release/?id=4d7aeae2-1 ea 1 -42da-acf1 b3cb2f1 aa230.

57. "To require the Securities and Exchange Commission to reinstate the 'uptick' rule and effectively regulate abusive short selling activities," S. 605, 111th Cong. $\S 3$ (2009), available at http://www.govtrack.us/congress/bill.xpd?bill=s111-605 (last visited Jan. 20, 2010).

58. See H.R. 302, 111th Cong. (2009) and H.R. 1406, 111th Cong. (2009), available at http://www.govtrack.us/congress/bill.xpd?bill=s111-605\&tab=related (last visited Jan. 20, 2010). 
It was also clear that the SEC was under pressure from the administration with respect to short selling. In an interview he gave to The Washington Post less than a month before he left the SEC, Chairman Cox stated that the biggest mistake of his tenure was agreeing to the September 2008 short selling ban on financial firms. ${ }^{59}$ Cox went on to state that "he had been under intense pressure from Treasury Secretary Henry M. Paulson Jr. and Fed Chairman Ben S. Bernanke to take this action and did so reluctantly." ${ }^{60}$ Fed Chairman Bernanke testified before the House Financial Services Committee in February 2009 that "In the kind of environment we have seen more recently," the uptick rule "might have had some benefit" in preventing the market collapse. ${ }^{61}$

The pressure about the uptick rule and short selling even reached into Presidential politics during the 2008 Presidential campaign. Senator John McCain, in a campaign speech on September 17, 2008, stated that the SEC had

kept in place trading rules that let speculators and hedge funds turn our markets into a casino. They allowed naked short selling ... [and] eliminated last year the uptick rule that has protected investors for 70 years ... The Chairman of the SEC serves at the appointment of the President and has betrayed the public's trust. If I were President today, I would fire him. ${ }^{62}$

In July 2007, repeal of the "uptick rule" educed little public notice. But in late 2007, the pressure and salience of the "uptick rule" had mounted to the point where the repeal of the rule was called a betrayal of public trust and grounds for the SEC Chairman's dismissal.

\section{IMPLiCATIONS AND CONCLUSION}

In many ways, short sale policy is a topic that generates more heat than light. Available data suggests that price tests are of limited use in a market trading in penny increments, and the SEC's gradual process of managing fails to deliver had worked down the threshold list to relatively small numbers of

59. Amit Paley \& David Hilzenrath, SEC ChiefDefends His Restraint, WASH. Post, Dec. 24, 2008, at A1.

60. Id.

61. Jesse Westbrook, Bernanke Says There May Be Benefit to Uptick Rule, BloomBerg.com, Feb. 25, 2009, http://www.bloomberg.com/apps/news?pid=20601087\&refer=home\&sid=a5.dyHLeI8a0 (last visited Jan. 20, 2010).

62. McCain's Scapegoat, WALl St. J., Sept. 19, 2008, at A22, available at http://online.wsj.com/ article/SB122178318884054675.html?mod=special_page_campaign2008_mostpop (last visited Jan. 20, 2010). 
firms.$^{63}$ In this light, the regulatory actions in 2008 and 2009 are anomalous, but certainly not costless. For example, SEC staff's own analysis of the efficacy of the July 2008 pre-borrowing requirement for the nineteen financial firms showed that while the Order decreased short selling, it had a number of other effects, or lack of effects, as well. ${ }^{64}$ While the pre-borrow did decrease failures to deliver, it had no effect on short interest in these firms. In particular, the memo states that stocks subject to the Order had "no changes in returns and no apparent dampening on downward returns. ${ }^{~}{ }^{65}$ The September 2008 short selling ban, by suddenly restricting their ability to short stock, caused funds that ran convertible bond strategies to lose substantial amounts of money as they were no longer able to manage the risk of their holdings. Similarly, statistical arbitrage strategies became infeasible without the ability to short stock, and such strategies can contribute liquidity to the market. These and other strategies suddenly became infeasible due to Commission action that had little prior public notice and limited economic justification in the rule release. It may be that the SEC, understanding that the emergency orders were limited to a duration of 30 calendar days, realized this short period allowed little time for a legal challenge to be brought by a person harmed by such Orders.

Perhaps most notable, but not surprising, was the ineffectiveness of the short selling Orders to halt the fall of stock prices. For example, during the period when the short selling ban was in effect, Morgan Stanley's stock fell by $42 \%$ over two days. That is, when no investors could sell the stock of Morgan Stanley short, the firm still lost almost half of its value in two days. Such a decline suggests that though short sellers may at times carry the message, they are not to root cause of the price decline. In fact, as Exhibit 3 shows, the broad price path of the stocks of major financial firms was a protracted and steady decline over a two-year period. This, coupled with what we now know about the problems in mortgage-related instruments and commercial real estate held by many of these firms, suggests that the short sellers were ultimately found to be correct in their beliefs.

63. For example, on December 31, 2007, there were only seventy-six firms on the NYSE threshold list. This number declined to only two names a year later, which is most likely due to Rule 204T, discussed above, which tightened delivery requirements. It is important to note that there are over

64. See Memorandum from Office of Economic Analysis to Distribution List on Analysis of the July Emergency Order Requiring a Pre-Borrow on Short Sales (Jan. 14, 2009), http://www.sec.gov/spotlight/ shortsales/oeamemo011409.pdf (last visited Jan. 20, 2010).

65. Id. at 2 . 
With regard to the SEC, the political influence on the rulemaking process can cause significant concerns for regulated entities. For one, rules that are passed for the wrong reason generally lead to ineffective and costly regulation, raising the costs of trade and making our markets less efficient. In addition, Congressional involvement signals to regulated entities that they should continue to target their lobbying efforts at Congress rather than directly at the Commission. Such efforts are likely to lead to more Congressional meddling in the workings of an agency whose work can likely be best done free from such influences.

This highlights one of the key balances that the SEC must strike and maintain. It must continue to operate as an independent executive agency while at the same time being responsive to Congress and its oversight committees. Congress provides the funding to the SEC, and without a growing budget, the SEC cannot hope to keep pace with the expansion of domestic and global capital markets. Its Commissioners are appointed by the President, but are confirmed by the Senate, further enmeshing Congress into the agency's workings.

The recent outcomes obtained to date with regard to short sale policy are far from satisfactory, but the process is still unfolding. The Commission has yet to act on the new price test rules, and is still considering whether to further tighten delivery requirements under Regulation SHO. For either set of rules, a vibrant market recovery is surely the best thing that can happen as it will remove short selling from the public mind and let the Commission proceed in a deliberative way, deciding on the basis of its substantial knowledge of the markets. With regard to the price test, the Commission has considerable latitude in its choices. Embedded within the proposing release are options that will allow the Commission, if it so chooses, to address populist concerns about short selling while implementing rules that have limited effect on the market.

The SEC remains a weakened agency compared to the position it enjoyed a few years ago. It faces the challenge of re-asserting its intellectual leadership over policy matters and substantive regulatory issues while not offending the agency's Congressional overseers. Short sale policy is perhaps a good policy area in which the Commission can reassert its rightful place, with an independent, content-driven, regulatory agenda. 


\section{Exhibit 1}

Timeline of selected SEC rules related to short selling

Date Method Rule purpose

Jan. $24,1938 \quad$ n/a

July 28, $2004 \quad$ Notice and Comment

July 14, 2006 Notice and Comment

July 28, 2007

Aug. 7, 2007

Mar. 16, 2008

July 7, 2008
Notice and Comment

Notice and Comment

Notice and Comment

Notice and Comment

Notice and Comment
Creates the Rule 10a-1 "uptick rule" that permits stocks to be sold short only on a plus or a zero-plus tick

New Regulation SHO requires, inter alia, that brokers locate shares before shorting stock and pre-borrow shares if the stock is on the Threshold List

Propose removal and/or tightening of SHO grandfather and options market maker exceptions

Repeal of Rule 10a-1, the "uptick rule"

Repeal SHO grandfather provision and propose removal of options market maker exception

Propose Rule 10b-21 naked short selling anti-fraud rule

Reopen comment on removing options market maker exceptions 
July 15, $2008 \quad 12(\mathrm{k})(2)^{*}$

July 18, $2008 \quad 12(\mathrm{k})(2)$

Sept. 17, $2008 \quad$ 12(k)(2)

Sept. 18, $2008 \quad$ 12(k)(2)

Sept. 18, $2008 \quad 12(\mathrm{k})(2)$

Sept. 21,2008 12(k)(2)

Sept. 21, $2008 \quad$ 12(k)(2)

Oct. $1,2008 \quad 12(\mathrm{k})(2)$
Emergency Order requiring a pre-borrow in Primary Dealer Credit Facility names

Amendments for markets makers, restricted securities, etc., for pre-borrow in PDCF names

Emergency Order to implement SHO Rule 204T to tighten obligations of brokers who fail to deliver securities to $\mathrm{T}+4$

Order requiring institutional managers to file daily short sale reports on Form SH that will be made public

Prohibits short selling of any financial firm listed in Appendix A of the Order

Amend previous 12(k)(2) Order to only require weekly non-public reports of short positions on Form $\mathrm{SH}$

Amends previous 12(k)(2) Order prohibiting short selling of any financial firm to give SROs the responsibility to designate the firms subject to the Order

Amend 12(k)(2) Order for SHO Rule 204T to incorporate staff guidance 
Oct. 2, $2008 \quad 12(\mathrm{k})(2)$

Oct. 14, $2008 \quad$ Interim Final

Oct. 14,2008

Oct. 14, 2008

Oct. 15, 2008

Apr. 10, 2009

Aug. 17, 2009
Interim Final

Notice and Comment

Notice and Comment

Notice and Comment

Notice and Comment
Extend previous 12(k)(2) short sale ban to run a total of 30 days or to 3 days after the President signs the Emergency Economic Stabilization Act

Adopt interim final $\mathrm{SHO}$ amendments for Rule 204T tightening close-out requirements to the morning of $\mathrm{T}+4$

Adopt Rule 10b-21 naked short selling anti-fraud rule

Regulation SHO adopting amendments to remove options market maker exception

Adopt interim final rule on the reporting of short position by institutional money managers

Propose a menu of new alternative short selling price tests, including restoration of the "uptick rule"

Propose additional comment on the new alternative short selling price tests, and ask additional questions

* $12(\mathrm{k})(2)$ is the Commission's emergency authority under Section 12(k)(2) of the 1934 Act 


\section{Exhibit 2}

List of NYSE Threshold Securities as of September 12, 2008

AbitibiBowater Inc.

Ambac Financial Group, Inc.

Arbor Realty Trust, Inc.

Assured Guaranty Ltd.

Aircastle Limited

Brookfield Homes Corporation

Brookdale Senior Living Inc.

Beazer Homes USA, Inc.

Cabela's Incorporated

Circuit City Stores, Inc.

Calgon Carbon Corporation

China Telecom Corporation Limited

Citizens, Inc.

Chipotle Mexican Grill, Inc.

The Colonial BancGroup, Inc.

China Security \& Surveillance

Technology

Carnival plc

Dillard's Inc.

DineEquity, Inc.

Downey Financial Corp.

Western Asset EM Floating Rate Fund

Western Asset EM Income Fund

Ethan Allen Interiors Inc.

First Commonwealth Financial Corp

Firstfed Financial Corp.

Morgan Stanley Frontier EM Fund, In

Fairfax Financial Holdings Limited

First Industrial Realty Trust, Inc.

Freddie Mac

FairPoint Communications, Inc.

Flotek Industries, Inc.

The Greenbrier Companies, Inc.

Griffon Corporation
CarMax Inc.

US Airways Group, Inc.

LDK Solar Co., Ltd.

LandAmerica Financial Group, Inc.

LG Display Co., Ltd.

Life Time Fitness, Inc.

La-Z-Boy Incorporated

MBIA Inc.

Media General, Inc.

The McClatchy Company

Martha Stewart Living Omnimedia

MGIC Investment Corporation

Meritage Homes Corporation

Vail Resorts, Inc.

Mueller Water Products, Inc.

Nordic American Tanker Shipping

Ltd.

National City Corporation

Newcastle Investment Corp.

National Financial Partners Corp.

Nuveen Muni High Inc. Opp.Fund 2

Realty Income Corporation

Polaris Industries Inc.

Pilgrim's Pride Corporation

Primus Guaranty, Ltd.

Pzena Investment Management, Inc.

. RAIT Financial Trust

Radian Group Inc.

Redwood Trust, Inc.

Seligman Select Municipal Fund,

Inc.

iStar Financial Inc.

Standard Pacific Corp.

Simpson Manufacturing Co., Inc.

Thompson Creek Metals Company 
Guaranty Financial Group Inc.

Greenhill \& Co., Inc.

General Motors Corporation

General Steel Holdings, Inc.

Hecla Mining Company

HEALTHSOUTH Corporation

Hovnanian Enterprises, Inc.

Harvest Energy Trust

J. Crew Group, Inc.

JER Investors Trust Inc.

KBW, Inc.
The Talbots, Inc.

Thornburg Mortgage, Inc.

Tootsie Roll Industries, Inc.

Tronox Incorporated

Trex Company, Inc.

Under Armour, Inc.

Vulcan Materials Company

VeraSun Energy Corporation

Wachovia Corporation

Western Refining, Inc.

Zale Corporation

NYSE list from http://www.nyse.com/threshold 


\section{Exhibit 3}

Prices of various financial firms 2007-2008

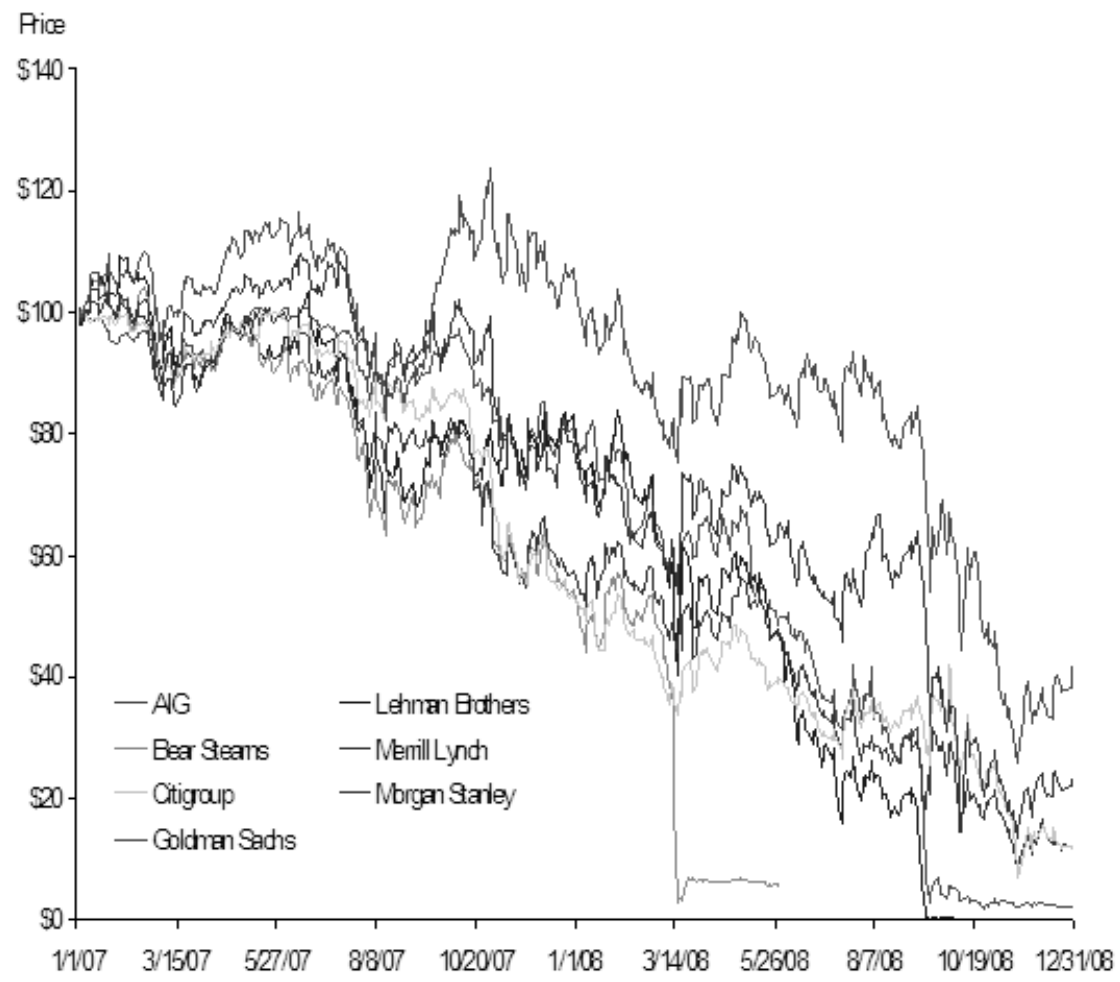

